\title{
Tantularisme, Pluralitas Agama dan Toleransi (Studi Kasus Masyarakat Ketanggi-Ngawi)
}

\author{
Moh. Toriqul Chaer \\ Sekolah Tinggi Ilmu Tarbiyah Karya Pembangunan, Paron Ngawi \\ Jawa Timur. \\ Email:toriqul_74@yahoo.com
}

\begin{abstract}
The objectives of this article are: first, to discover the background of religious pluralism in Javanese society, notably among the communities in Ketanggi; second, to explore religious practices in Ketanggi; and third, to explore the religious attitudes of Ketanggi people towards religious pluralism. This article is based on field research carried out in Ketanggi sub-district of Ngawi, East Java, which is inhabited by the communities with different religious backgrounds. This paper argues that religious commitment among Ketanggi people is partly based on 'tantularisme', a sort of ethical principle which emerges as a result of the encounters between religion and local wisdom. The reception of Ketanggi people towards religious and cultural pluralism is partly expressed in the concept of lilo legowo (voluntary reception towards the other) which in turn become foundation of religious tolerance in that area.

Keywords: religious pluralism, tantularism, and Javanese culture.
\end{abstract}

\section{ABSTRAK}

Artikel ini bertujuan untuk: pertama, mengungkap latar belakang pluralitas agama pada masyarakat Jawa, khususnya pluralitas agama pada masyarakat Ketanggi; kedua, mengetahui realitas yang berkembang dari pemahaman dan praktek keagamaan masyarakat Ketanggi; ketiga, mengetahui komitmen keagamaan masyarakat Ketanggi terhadap pluralitas agama. Fokus penelitian ini adalah Kelurahan Ketanggi, bagian dari Kecamatan Ngawi yang memiliki pluralitas agama pada masyarakatnya. Penelitian ini diantaranya berkesimpulan bahwa komitmen keagamaan masyarakat Ketanggi dibangun atas pemahaman "tantularisme" merupakan sinergi agama dan budaya yang melahirkan produk kearifan lokal, sebagaimana dijumpai pada Kelurahan Ketanggi pluralitas agama dan budaya disikapi dengan "lilo legowo" (penerimaan secara suka rela) yang bermetamorfosis menjadi perilaku toleransi terhadap keberagaman.

Kata kunci: pluralitas agama, tantularisme dan budaya Jawa

\section{PENDAHULUAN}

Masyarakat Indonesia adalah masyarakat yang plural, hal ini dapat dilihat dari keberagaman suku bangsa, bahasa lokal, agama, adat dan budaya yang ada. Bagi suatu masyarakat pluralistik seperti Indonesia, potensi konflik sangat dimungkinkan terjadi. Ragam konflik bisa bersumber dari berbagai hal, seperti: konflik antar agama, konflik antar etnis, konflik antar budaya, konflik antar suku ataupun konflik kepentingan antar masyarakat dari daerah atau propinsi yang berbeda.

Adalah sebuah keniscayaan dalam masyarakat plural bahwa klaim kebenaran (truth claim) dan watak missioner dari setiap agama dapat mendorong terjadinya benturan- 
benturan dalam kehidupan beragama dan timbulnya salah pengertian antar penganut agama menjadi terbuka lebar. Setiap agama menyatakan ajarannya sebagai totalitas sistem makna yang berlaku bagi seluruh kehidupan, baik individual maupun sosial. ${ }^{1}$ Pemahaman agama pada masyarakat Indonesia dipahami secara umum sebagai sistem kepercayaan, tingkah laku, nilai, pengalaman dan yang terinstitusionalisasi, diorientasikan kepada masalah spiritual/ritual yang disalingtukarkan dalam sebuah komunitas dan diwariskan antar generasi dalam tradisi. Penegasan yang ingin disampaikan di sini adalah bahwa konsekuensi dari pemahaman keagamaan yang kaku, tidak bersifat scientific justru akan memunculkan stigmatisasi negatif terhadap peran penting agama dalam relasi kemanusiaan. Stigmatisasi tersebut berpandangan bahwa agama identik dengan dogmatism, rigidity, excessive self-blaming dan gender bias.

Pada masyarakat Jawa, pendewaan dan pemitosan terhadap ruh nenek-moyang melahirkan penyembahan ruh nenekmoyang (ancestor worship) yang melahirkan hukum adat dan relasi-relasi pendukungnya. Pelaksanaan upacara-upacara selametan ruh nenek-moyang menjadi sebentuk dewa pelindung bagi keluarga yang masih hidup. Stange menyebutnya sebagai "kesetiaan spiritual” yang dikondisikan oleh adanya semangat budaya. Agama bagi masyarakat Jawa agama juga tidak terlalu dipermasalahkan, karena masyarakat Jawa memiliki pemahaman dan pemaknaan sendiri terhadap agama: "agama ageming aji" (agama sebagai sarana kebaikan dan kebajikan), apa pun agama yang dipeluk sama saja karena semua agama mengajarkan keselamatan. $^{2}$
Pemaknaan dari kata "aji” yaitu dengan pengertian "ratu" yang menjelaskan bahwa agama yang dipeluk oleh raja atau ratu itulah agama yang dipeluk oleh masyarakatnya. ${ }^{3}$ Tidak heran jika masyarakat Jawa dahulu berubah-ubah agamanya, dan perbedaan agama ini terjadi karena mengikuti dari agama dan keyakinan raja atau ratunya. Tipologi pemaknaan agama ini pada akhirnya menjadikan pluralitas, keberagaman terjadi dan banyak dijumpai pada masyarakat Jawa. Pemaknaan tersebut masih berlaku sampai sekarang. Sehingga tidak heran dijumpai pada masyarakat Jawa dalam keluarganya terdapat lebih dari satu macam agama. Masyarakat Jawa beranggapan bahwa "semua agama itu mengajarkan kebaikan jadi terserah mau memilih agama apa saja, karena agama hanyalah untuk sarana menuju kepada kehidupan yang kekal (surga)”.

Aktualisasi komitmen keagamaan dalam wujud toleransi luar biasa ini menjadi dasar semangat untuk menghormati, menghayati serta mengamalkan semua nilai kebenaran dari manapun sumbernya yang dilandasi keyakinan orang Jawa, agama hanyalah untuk sarana menuju kehidupan yang kekal dan pemahaman bahwa "sadaya agami punika sami" (semua agama hakekatnya adalah sama). ${ }^{4}$ Muhaimin menambahkan bahwa sisi moralitas, harmonisasi dan etis pada masyarakat Jawa yang perlu digaris bawahi adalah; adanya sifat toleran, akomodatif dan kelenturan (flexibility) dari masyarakat Jawa itu sendiri. ${ }^{5}$

Daerah Jawa adalah daerah persilangan. Sebagai sebuah persilangan, kenyataan bahwa Jawa telah dilalui beragam kebudayaan dengan keunikan dan kekayaan masingmasing. ${ }^{6}$ Koentjaraningrat menegaskan 
bahwa dalam masyarakat Jawa terdapat dua batasan yaitu batasan masyarakat Jawa secara utuh atau menurut geografisnya. Secara kultural masyarakat Jawa adalah masyarakat yang memiliki identitas baik itu berbahasa Jawa dan berkebudayaan Jawa meskipun tidak tinggal di pulau Jawa. Dalam khazanah nilai-nilai tradisi, masyarakat Jawa selalu berpegang teguh landasan dan filosofi orang Jawa yang mengedepankan keselarasan sosial dan mempunyai solidaritas yang tinggi.

Berdasar data pada Balai Penelitian, Pengembangan dan Statistik Kabupaten Ngawi, ${ }^{7}$ di Kabupaten Ngawi secara keseluruhan tercatat terdapat 1.382 masjid, 3.960 mushola, 77 gereja, 1 kuil dan 1 klenteng. Pada Kecamatan Ngawi didapati 87 Masjid, 135 mushola, 13 gereja, 1 kuil dan 1 klenteng. Jika melihat data dari Balai Penelitian, Pengembangan dan Statistik Kabupaten Ngawi, maka didapati pluralitas agama pada wilayah Kecamatan Ngawi, khususnya pada Kelurahan Ketanggi yang secara administratif masuk dalam wilayah Kecamatan Ngawi.

Keunikan pluralitas agama pada Kelurahan Ketanggi ditunjukkan dengan adanya tempat ibadah agama yang berbeda dan saling berdekatan, antara masjid, gereja dan klenteng dalam satu kelurahan, khusus bagi klenteng merupakan satu-satunya klenteng yang ada di Kabupaten Ngawi. Keunikan lainnya adalah adanya pluralitas etnis yang tersebar pada lingkungan Sido Makmur. Kelurahan Ketanggi juga sentra bisnis dan urat nadi perekonomian di Kabupaten Ngawi. Pluralitas pada masyarakat Ketanggi inilah yang menjadi daya tarik untuk dijadikan lokasi kajian penelitian. Kelurahan Ketanggi dijadikan sebagai lokasi penelitian, terutama pada aspek kajian bagaimana pluralitas agama terjadi, bagaimana pemahaman dan praktek keagamaan serta komitmen keagamaan pada masyarakat Ketanggi. Dengan mengamati kenyataan di atas mendorong minat peneliti untuk melakukan studi penelitian tentang pluralitas agama pada masyarakat Jawa (Studi Komitmen Keagamaan Masyarakat Ketanggi, Kecamatan Ngawi, Kabupaten Ngawi).

Berdasar latar belakang di atas, artikel ini membahas beberapa persoalan pokok sebagai berikut: Mengapa terjadi pluralitas dalam masyarakat Jawa, khususnya keberagaman agama pada masyarakat Ketanggi? Bagaimana pemahaman dan praktek keagamaan pada masyarakat Ketanggi? Bagaimana komitmen keagamaan masyarakat Ketanggi terhadap pluralitas agama?

\section{ANALISIS TEORETIK: PLURALITAS AGAMA PADA MASYARAKAT KETANGGI}

Kerangka teori yang peneliti gunakan merupakan konsep teori beragama unifying factor yang digagas oleh Gordon W. Allport dan teori collective consciousness serta religion as a societal glue-nya Emile Durkheim. Dalam kajian Allport, cara beragama yang menjadikan agama sebagai unifying factor; menjadikan agama sebagai falsafah hidup dan kehidupan yang menekankan aspek kasih sayang disebut sebagai "cara beragama intrinsik" yang dapat menciptakan lingkungan masyarakat yang harmonis, damai dan penuh kasih sayang.

Agama dalam kajian Durkheim merupakan perwujudan dari collective consciousness (kesadaran kolektif) walau pada realitasnya dapat ditemui adanya perwujudanperwujudan lainnya. Dalam analisa Durkheim agama adalah sarana untuk memperkuat kesadaran kolektif seperti ritus- 
ritus agama yang membuat pelaku yang terlibat (involved) dalam upacara keagamaan dengan harapan kesadaran mereka tentang collective consciousness semakin bertambah kuat. Tesis Durkheim "religion as a societal glue" merupakan antitesa pemikiran agama pada satu sisi memiliki potensi yang bersifat destruktif yang terjadi karena klaim kebenaran agama (truth claim) yang berlebihlebihan tetapi agama pada sisi yang lain juga merupakan wahana konstruktif bagi adanya interaksi dan dialog antar umat beragama, mewujudkan persatuan sosial, mempertahankan integrasi, keutuhan dan keteraturan sosial sehingga konflik, kerusuhan dan kekerasan massa dapat dihindari.

Berikut adalah deskripsi proses berpikir dalam kajian Pluralitas Agama Masyarakat Jawa dengan aksentuasi kajian pada pembahasan komitmen keagamaan masyarakat Ketanggi, Kecamatan Ngawi Kabupaten Ngawi.

GAMBAR 1. KERANGKA BERPIKIRUNIFYING FACTOR (GORDON W. ALLPORT)

Unifying Factor (Gordon W. Allport) Collective consciousness Religion as a societal glue (Emile Durkheim)

Secara filosofis, pluralitas dibangun dari prinsip pluralisme, yaitu sikap, pemahaman dan kesadaran terhadap kenyataan adanya kemajemukan, keragaman sebagai sebuah keniscayaan, sekaligus ikut secara aktif memberikan makna signifikannya dalam konteks pembinaan dan perwujudan kehidupan berbangsa dan bernegara ke arah manusiawi yang bermartabat.

Pluralitas adalah keragaman dalam sebuah wujud persatuan. Keragaman, keunikan, dan parsial itu merupakan realitas yang tak terbantahkan, secara sosiologis, manusia terdiri dari berbagai etnis dan budaya yang saling berbeda dan mengikat dirinya antara satu dengan lainnya. Salah satu yang paling penting dalam ranah pluralitas adalah sesuatu yang terkait dengan kepercayaan atau agama yang dianut oleh masyarakat.

Pluralitas agama sangat mewarnai sejarah kehidupan, sosial, tidak terkecuali masyarakat kontemporer, baik dalam skala kecil maupun skala besar, terutama pada negara-negara yang sangat mengedepankan religiusitas. Keragaman agama, sebagaimana keragaman etnisitas suku dan bangsa, juga dipahami dalam satu perspektif kemanusiaan yang hidup berdampingan dengan kekhasannya membangun kehidupan bersama, keunikan ini bukanlah ancaman terhadap pemeluk agama yang satu terhadap eksistensi agama yang lainnya, tetapi akan lebih memperjelas keunikan sendiri. Agama yang dianut oleh seorang pemeluknya menjadi identitas pribadinya sekaligus cerminan kesucian agamanya.

Indonesia merupakan salah satu di antara sedikit negara di dunia yang memiliki karakteristik sebagai negara multietnik. Di Indonesia diperkirakan terdapat 931 etnik dengan 731 bahasa. Indonesia juga merupakan sebuah negara yang memiliki tradisi agama yang cukup kuat. Ada lima agama besar di Indonesia, yakni Islam, Katolik, Protestan, Hindu, dan Buddha. ${ }^{8}$ 
Struktur masyarakatnya ditandai oleh dua cirinya yang unik, yaitu: secara horizontal, ia ditandai oleh kenyataan adanya kesatuankesatuan sosial berdasarkan perbedaanperbedaan suku bangsa, agama, adat, serta perbedaan-perbedaan kedaerahan.

Sedangkan secara vertikal, struktur masyarakat Indonesia ditandai oleh adanya perbedaanperbedaan antara lapisan atas dan lapisan bawah yang cukup tajam.

Perbedaan-perbedaan suku bangsa, agama, adat, dan kedaerahan seringkali disebut sebagai ciri masyarakat Indonesia yang bersifat majemuk, suatu istilah yang mulamula dikenalkan oleh Furnivall untuk menggambarkan masyarakat Indonesia pada masa Hindia Belanda. Konsep masyarakat majemuk sebagaimana yang digunakan oleh ahli-ahli ilmu kemasyarakatan dewasa ini memang merupakan perluasan dari konsep Furnivall tersebut. Masyarakat Indonesia pada masa Hindia Belanda, menurut Furnivall, merupakan suatu masyarakat majemuk (plural society), yakni suatu masyarakat yang terdiri atas dua atau lebih elemen yang hidup sendiri-sendiri tanpa ada pembauran satu sama lain di dalam kesatuan politik. ${ }^{9}$

Pluralitas agama atau kebhinekaan agama merupakan kenyataan aksiomatis (tidak bisa dibantah), dan merupakan keniscayaan sejarah (historical necessary) yang bersifat universal. ${ }^{10}$ Pluralitas agama harus dipandang sebagai bagian dari kehidupan manusia, yang tidak dapat dilenyapkan, tetapi harus disikapi. Dalam menyikapi pluralitas agama tersebut, lahirlah konsep-konsep mengenai sikap keagamaan yang diusung oleh beberapa tokoh. Misalnya, Hans Kung yang mempromosikan ide global ethics, John Hick mengusulkan global theology. Pemikiran eksklusif dari agama-agama diglobalkan dan dilebur agar dikenal dengan gagasan yang disebut teologi inklusif. Teologi ini menekankan bahwa semua agama pada esensinya adalah sama, semuanya benar karena tanpa kecuali seluruhnya mengajarkan kebaikan dan ketundukan kepada Yang Maha Kuasa dan Maha Benar. Oleh sebab itu, tidak ada satu pun di antara agama yang ada pada saat ini lebih superior dibandingkan yang lain.

Menurut Komaruddin Hidayat, tipologi sikap keagamaan terdiri dari lima tipe, yaitu; ekslusivisme, inklusivisme, pluralisme, eklektivisme, dan universalisme. Ekslusivisme adalah sikap keagamaan yang memandang bahwa ajaran yang paling benar adalah agama yang dipeluknya, yang lainnya sesat. Insklusivisme adalah sikap keagamaan yang berpandangan bahwa di luar agama yang dipeluknya, juga terdapat kebenaran, meskipun tidak seutuh dan sesempurna agama yang dianutnya. Pluralisme adalah sikap keagamaan yang berpandangan bahwa secara teologis, pluralitas agama dipandang sebagai realitas niscaya yang masing-masing berdiri sejajar sehingga semangat misionaris dan dakwah dianggap "tidak relevan".

Eklektivisme adalah sikap keagamaan yang berusaha memilih dan mempertemukan berbagai ajaran agama yang dipandang baik dan cocok untuk dirinya sehingga format akhir dari sebuah agama menjadi semacam mozaik eklektik. Universalisme adalah sikap keagamaan yang berpandangan bahwa pada dasarnya semua agama adalah satu dan sama, hanya karena faktor historis yang menyebabkan agama tampil dalam format yang plural. ${ }^{11}$

Dalam konteks Islam, mereka menolak interpretasi ulama atau umat Islam atas surat 
Ali Imran: 197 yang menekankan

superioritas Islam atas agama lainnya.

Qurasih Shihab menerjemahkan Q.S. Ali

Imran: 19, sebagai berikut,

"Sesungguhnya agama (yang disyariatkan) di sisi Allah adalah Islam. Tidak berselisih orangorang yang telah diberi al-Kitab kecuali sesudah datang pengetahuan kepada mereka karena kedengkian (yang ada) di antara mereka. Barangsiapa yang kafir terhadap ayatayat Allah maka sesungguhnya Allah sangat cepat hisab-Nya". ${ }^{12}$

\section{TENTANG MASYARAKAT KETANGGI}

Pada masyarakat Ketanggi interaksi agama dan budaya terjadi secara masif, hal ini karena potensi yang dimiliki Ketanggi selain sebagai pusat bisnis di wilayah Kabupaten Ngawi, juga merupakan pusat pemerintahan kabupaten. Dengan jarak tempuh hanya kurang dari 500 meter ke pusat pemerintahan dan adanya pusat bisnis yang menawarkan ragam dan aneka kebutuhan bagi masyarakat Kabupaten Ngawi menjadikan Ketanggi menjadi tujuan bagi para pendatang dari luar Kabupaten Ngawi untuk berinvestasi dan menetap di Ketanggi.

\section{Pusat bisnis di Kelurahan Ketanggi} diantaranya berada di sepanjang Jalan AR. Suprapto dan Jalan Sultan Agung yang sebagian besar didominasi oleh pertokoan yang menawarkan aneka produk makanan, garment dan elektronik. Pusat bisnis lainnya ada di sepanjang Jalan Ronggowarsito di Jalan Dr. Sutomo banyak dijumpai toko-toko yang melayani kebutuhan sehari-hari, diantaranya Alfa Mart dan Indomaret, pusatpusat hiburan serta Toko Delima sebagai pusat grosir alat-alat pendidikan di Kabupaten Ngawi. Keberadaan Pasar Besar Ngawi di Jalan Mangkubumi, Ketanggi turut andil dalam meningkatkan laju pertumbuhan dan perkembangan roda perekonomian di wilayah Ketanggi. Keberadaan Pasar Besar Ngawi sebagai pusat ekonomi kerakyatan menjadikan Kelurahan Ketanggi berkembang dinamis dari segi pertumbuhan perekonomian bila dibandingkan dengan daerah-daerah lainnya di wilayah Kabupaten Ngawi.

Selain sebagai tempat tujuan pemenuhan aneka kebutuhan hidup sehari-hari masyarakat Ngawi, Ketanggi juga sering dijadikan sebagai tempat pergelaran pelbagai acara yang diselenggarakan di Kabupaten Ngawi, terutama pada momen peringatan Hari Jadi Kabupaten Ngawi. Pada beberapa perayaan yang berkenaan dengan upacara protokoler kedinasan atau pemerintahan, maka wilayah Ketanggi selalu menjadi prioritas utama sebagai tempat penyelenggaraannya, hal ini bisa dimaklumi karena keberadaan alun-alun Kabupaten Ngawi berada di wilayah Ketanggi.

Tingkat pertumbuhan ekonomi yang tinggi menjadikan Ketanggi tujuan utama bagi para pelaku ekonomi untuk melakukan ekspansi dan investasi perdagangan. Hal ini menjadikan Ketanggi memiliki intensitas interaksi budaya, agama dan etnik yang pada akhirnya menjadikan Ketanggi sebagai wilayah yang pluralis etnis dan agama bila dibandingkan dengan wilayah-wilayah yang lain di Kabupaten Ngawi. Keunikan pada aspek keberagaman agama, budaya dan etnis menyebabkan kelurahan Ketanggi berbeda dengan kelurahan yang lain di wilayah Kabupaten Ngawi. Pada kelurahan Ketanggi pluralitas agama dan kerukunan umat beragama tidak hanya terjadi pada tingkat masyarakat, tetapi juga terjadi pada tingkat keluarga. 
Peneliti mendapati beberapa keluarga yang memiliki latar belakang agama yang berbeda, diantaranya keluarga Hendrik (57 tahun) yang berdomisili di Jalan Mangkubumi. Pada keluarga Hendrik terdapat pluralitas agama, beliau sebelumnya beragama Kristen lalu pindah agama Buddha dan anak-anak beliau diantaranya menganut agama Kristen dan Katolik. Meskipun terjadi perbedaan agama dalam berkeluarga peneliti tidak mendapati pertikaian atau konflik yang bersumber pada masalah agama dan etnik dalam keluarga yang terdapat pluralitas agama.

Beliau mengatakan bahwa komitmen untuk membangun suasana kehidupan keagamaan di tingkat keluarga yang rukun dan harmonis berdasar pada keyakinan pengamalan nilai-nilai agama yang mereka yakini untuk berbuat yang terbaik kepada sesama manusia (Hasil wawancara dengan Hendrik (57 tahun) pada tanggal 19 Oktober 2011). Pemahaman pluralitas agama pada masyarakat Ketanggi melihat apa yang disampaikan oleh Hendrik (57 tahun) lebih kental adanya kekuatan pemahaman keluhuran ajaran agama yang mereka anut. Disamping itu pengaruh dari budaya Jawa yang menekankan sikap sinkretis menjadikan potensi konflik pada pluralitas agama dapat diredam. Tidak hanya sekedar bahasa retorika, tetapi memberikan contoh dalam perbuatan, bagaimana menghargai perbedaan termasuk perbedaan agama.

Johan Hendrik Caspar Kern dalam karangannya "Over de Vermenging van Civaisme en Buddhisme op Java, naa aanleiding van het Oudjavaansch gedicht Sutasoma" tidak menggunakan istilah sinkretisme tetapi menggunakan istilah vermenging; yang artinya percampuran. Sementara itu Gonda menyebutnya dengan istilah coalition, disamping itu ada yang menamakannya sebagai blending (pemaduan), fusion (peleburan) dan amalgation (amalgamasi; peleburan). Istilah sinkretisme dan sinkretisme Jawa digunakan Rasers yang menggunakan istilah "agama Jawa" untuk menamai produk percampuran agama yang terjadi pada masyarakat Jawa. ${ }^{13}$

Dari uraian diatas dapat peneliti simpulkan bahwa hubungan mesra antar agama pada masyarakat Jawa, baik Jawa Tengah maupun Jawa Timur, terutama Jawa Tengah bukan hanya sekedar sinkretisme Jawa melainkan toleransi yang luar biasa dari masyarakat Jawa yang dilandasi semangat untuk menghormati dan menghayati serta mengamalkan semua nilai kebenaran, dari manapun sumbernya. Semangat ini identik dengan tantularisme; jika ditarik sumbernya tersirat dari kalimat yang disampaikan oleh Empu Tantular bhinneka tunggal ika tan hana dharma mangrwa (berbeda-beda tetapi tetap satu).

Pluralitas agama yang terjadi di Ketanggi bukanlah halangan untuk membangun hubungan dialogis antar umat beragama, hal ini dikarenakan semangat kebajikan (sabba Danam Dhamma Danam Svaha). Semangat pembauran yang dilakukan oleh etnis Tionghoa dilakukan dengan kesadaran bahwa apa yang mereka lakukan adalah upaya untuk menjadi bagian dari masyarakat Ketanggi (Hasil wawancara dengan Ali Handoyo (71 tahun), Pengurus Klenteng Sie Hien Kyong, Ngawi pada tanggal 26 Oktober 2011). Dari uraian di atas, maka dapat disimpulkan yang menjadi kekuatan dialog harmonisasi pluralitas agama dan etnis pada masyarakat Ketanggi merupakan upaya pemahaman agama sebagai comprehensive commitment, dan driving integrative motive yang 
mengatur seluruh aspek kehidupan manusia disamping adanya faktor budaya masyarakat Jawa yang menekankan harmoni (keselarasan).

Agama dimengerti, dipahami dan diterima sebagai faktor pemadu (unifying factor) sebagaimana yang digagas oleh Gordon W. Allport, atau dengan kata lain cara beragama yang menjadikan agama sebagai panduan, falsafah dalam hidup dan kehidupan. Cara beragama seperti ini aplikasi nilai ajaran-ajaran agama menghunjam ke dalam diri penganutnya dan dipraktekkan dalam hidup dan kehidupan. Dalam kajian Allport, cara beragama yang menjadikan agama sebagai falsafah hidup dan kehidupan yang menekankan aspek kasih sayang disebut sebagai "cara beragama intrinsik" yang mampu menciptakan lingkungan masyarakat yang harmonis, damai dan penuh kasih sayang. Pemahaman ajaran agama sebagai ajaran untuk berbuat baik terhadap sesama diyakini oleh masyarakat Ketanggi, dipahami dan diterapkan dalam kehidupan sehari-hari. Orang Jawa tidak bisa lepas dari masyarakat mereka; masyarakat itu otonom serta mengatur keseluruhan hidup para pesertanya. Rust en orde demikian Niels Mulder menyebut ketentraman dan keselarasan masyarakat Jawa yang merupakan dasar moralitas; dasar itu terletak dalam hubungan yang laras antara orang dalam masyarakat mereka sendiri. ${ }^{14}$

Harmonisasi suasana pluralitas agama pada masyarakat Kelurahan Ketanggi didukung pula adanya peran aktif dari para pemuka agama yang menekankan pada para pengikut/jamaahnya untuk selalu berbuat baik dan untuk selalu bisa menghargai perbedaan yang ada pada masyarakat Ketanggi. Catatan kelam bernuansa agama memang pernah terjadi pada tahun 1980 di wilayah Ketanggi akan tetapi konflik tersebut dipicu oleh adanya proses dakwah internal yang dilakukan oleh agama tertentu dengan kaku, ekstrem dan cenderung anarkis. Peristiwa tahun 1980 bukan merupakan konflik atas nama agama, akan tetapi merupakan persoalan internal agama berkaitan dengan cara dakwah yang dilakukan oleh golongan/organisasi tertentu (hasil wawancara dengan Lurah Ketanggi pada tanggal 25 Oktober 2011).

Terciptanya kondisi keberagaman yang kondusif juga tidak terlepas dari peran andil pemerintah, dalam hal ini pemerintah Kabupaten Ngawi dalam menciptakan kerukunan antar umat beragama. Salah satu upaya untuk menjembatani hubungan antar umat beragama pemerintah menyediakan wadah bagi para pemuka agama untuk berdialog dan mencari solusi atas permasalahan yang terjadi di masyarakat, yaitu Forum Kerukunan Umat Beragama (FKUB). FKUB ini bertujuan sebagai penyambung aspirasi masyarakat beragama di Kabupaten dengan pemerintah. Selain itu FKUB bertujuan untuk memberikan pemahaman kepada masyarakat arti penting dari kesadaran hidup beragama dalam suasana pluralitas agama. Terlepas dari pro dan kontra, semangat pendirian FKUB pada hakekatnya merupakan bentuk apresiasi pemerintah terhadap suasana keberagaman agama di masyarakat.

\section{ANALISA PEMAHAMAN DAN PRAKTEK KEAGAMAAN PADA MASYARAKAT KETANGGI}

Masyarakat Ketanggi selain plural agama, juga plural secara etnis. Penduduk yang tinggal di lingkungan Ketanggi sebagian besar 
adalah warga pendatang etnis Tionghoa yang lahir dan hidup di Jawa. Ajaran leluhur etnis Tionghoa terus diamalkan dan dipelihara secara turun-temurun, sekalipun mereka sudah menganut suatu agama atau kepercayaan yang berbeda dengan agama dan kepercayaan yang dianut oleh nenek moyang mereka. Etnis Tionghoa Ketanggi melakukan praktek ritual di Klenteng Sie Hien Kyong, Ngawi sebagaimana tradisi ritual dan kepercayaan terhadap roh, wali keramat maupun benda-benda magis pada masyarakat Jawa pribumi yang masih tetap mengakar dalam kebudayaan masyarakat Jawa.

Dalam masyarakat Jawa pendewaan dan pemitosan terhadap ruh nenek moyang melahirkan penyembahan ruh nenek moyang (ancestor worship) yang pada akhirnya melahirkan hukum adat dan relasi-relasi pendukungnya. Dengan upacara-upacara selamatan, ruh nenek moyang menjadi sebentuk 'dewa pelindung' bagi keluarga yang masih hidup. ${ }^{15}$ Melakukan upacara atau ritual ditempat-tempat keramat adalah suatu tindakan religius yang merupakan bagian dari kebudayaan. Kegiatan ini dilandasi dan didorong oleh adanya emosi keagamaan, sebuah getaran spiritual yang dipercaya mampu menggerakkan jiwa manusia. Beberapa pakar agama menyebutkan bahwa aktifitas ritual merupakan proses dimana jiwa manusia dimasuki cahaya Tuhan. ${ }^{16}$

Praktek ritual dalam bahasa Underhill (1992) selalu ditujukan kepada Tuhan, betapapun tebalnya selubung yang digunakan untuk memahami-Nya dan betapapun anehnya penyamaran yang dipakainya. Ciri ibadat ini ialah adanya keseimbangan antara lahir dan batin, karena manusia tidak hanya terbuat dari akal atau spirit saja. ${ }^{17}$ Ciri ibadat ini ialah adanya keseimbangan antara lahir dan batin, karena manusia tidak hanya terbuat dari akal atau spirit saja. ${ }^{18}$ Ahli-ahli kebudayaan berpandangan bahwa pengenalan terhadap tradisi seperti ini berawal dari pemujaan roh dan benda-benda. Pemujaan pada roh disebut dengan animisme dan pemujaan pada benda mati disebut dinamisme. Animisme dan dinamisme merupakan religi Jawa tertua yang mewarnai keyakinan masyarakat. Keyakinan itu terwujud nyata dalam pemujaan roh dan kekuatan benda melalui permohonan berkah.

Ekspresi-ekspresi ritual dalam praktik sekarang ini juga tampak pada perpaduan antara unsur- unsur Islam dengan budaya lokal. Contoh yang paling populer dan hingga saat ini masih menjadi polemik di kalangan umat Islam adalah peringatan untuk mendoakan orang- orang yang sudah meninggal dunia, yaitu pada hari ke 3, 7, 40, 100 dan 1000 hari dari kematiannya. Acara ritual ini dalam tradisi sekarang disebut selametan, sebuah kata yang diderivasi dari bahasa Arab yaitu islam, salam dan salamah yang berarti memohon keselamatan dan kedamaian, upacara ini sering dikaitkan dengan istilah tahlilan atau tahlil yaitu membaca kalimat thayyibah, la ilaha illa Allah bersama-sama.

Bagi orang Jawa, khususnya masyarakat Ketanggi, pemahaman bahwa hidup ini dipenuhi dengan upacara-upacara, baik upacara yang berkaitan dengan lingkungan maupun upacara yang bersifat sakralritualistik. Upacara ini mengiringi kehidupan manusia sejak dari keberadaannya dari perut ibu, lahir, anak-anak, remaja, dewasa, sampai saat kematiannya disamping itu juga upacara kegiatan sehari-hari dalam mencari nafkah. Dalam hal ini secara luwes Islam 
memberikan warna baru pada upacaraupacara itu, diantaranya kenduren atau selametan, mitoni, sunatan dan lain lain. ${ }^{19}$

Utsman Najati dalam bukunya Al-Qur'an dan Ilmu Jiwa Agama, mengatakan bahwa keimanan Tuhan memiliki kekuatan yang luar biasa yang membekali manusia yang lebih religius dan kekuatan rohaniyah yang menopang dalam menanggung beban hidup, menghindarkannya dari keresahan yang menimpa banyak manusia modern yang dalam hidupnya didominasi oleh kehidupan materi dan persaingan keras guna mendapatkan materi, tapi pada saat tertentu manusia membutuhkan hidangan ruhaniyah. Menurut Djam'annuri, hal paling utama yang membedakan perbuatan-perbuatan ibadat dengan perbuatan- perbuatan manusia yang lain adalah niat (intension), atau tujuannya, bukan perbuatan itu sendiri. ${ }^{20} \mathrm{Di}$ sinilah lebih terletak perbedaan penting antara agama- agama etnis dengan agamaagama universal dalam mengungkapkan pengalaman agama secara teoritis atau intelektual. Agama etnis menekankan pada ketelitian dan ketepatan pelaksanaan perbuatan itu sendiri, opus operantum, sementara agama-agama universal lebih memberikan penilaian pada sikap batin dan tujuan (niat) perorangan sebagai ukuran kemurnian iman. Tanpa sikap batin dan niat yang benar, pelaksanaan suatu perbuatan keagamaan tidak akan ada nilainya sama sekali.

Pemahaman masyarakat Ketanggi akan pentingnya menjalankan ajaran agama dengan baik dan benar sebagai suatu kewajiban yang harus dipenuhi. Pada sisi yang lain mereka juga memiliki kewajiban untuk menjaga tradisi yang terbungkus dalam ritual dan upacara. Dalam proses selanjutnya antara agama dengan budaya pada masyarakat Ketanggi saling berinteraksi, saling mengisi dan saling mempengaruhi. Sinergi tradisi keagamaan dan sikap keagamaan masyarakat Ketanggi terjadi saling melengkapi, pada satu sisi sikap keagamaan yang mereka miliki mendukung terbentuknya tradisi keagamaan, sedangkan tradisi keagamaan sebagai lingkungan kehidupan turut memberi nilai dan norma dari pola tingkah laku keagamaan masyarakat Ketanggi itu sendiri. Dengan demikian, tradisi keagamaan memberi pengaruh dalam membentuk pengalaman dan kesadaran agama sehingga terbentuk dalam sikap keagamaan masyarakat yang hidup dalam lingkungan tradisi tertentu.

Agama dalam bahasa Durkheim merupakan perwujudan dari collective consciousness (kesadaran kolektif) sekalipun selalu ada perwujudan-perwujudan lainnya. Tuhan dianggap simbol dari masyarakat itu sendiri yang sebagai collective consciouness kemudian menjelma ke dalam collective representation. Tuhan merupakan idealisme dari masyarakat itu sendiri yang menganggapnya sebagai makhluk yang paling sempurna (Tuhan adalah personifikasi masyarakat) dan melebihi apa yang dimiliki oleh manusia. Dalam hal ini Durkheim mengemukakan dua hal pokok dalam agama yaitu kepercayaan dan ritus/ upacara-upacara. Keyakinan adalah pikiran dan ritus adalah tindakan.

Agama adalah sarana untuk memperkuat kesadaran kolektif seperti ritus-ritus agama. Orang yang terlibat dalam upacara keagamaan maka kesadaran mereka tentang collective consciouness semakin bertambah kuat. Keberlanjutan upacara keagamaan suasana keagamaaan dibawa dalam kehidupan sehari-hari, kemudian lambat laun 
collective consciousness tersebut semakin lemah kembali. Jadi ritual-ritual keagamaan pada masyarakat Ketanggi merupakan sarana yang dianggap mampu berperan dalam menciptakan kesadaran kolektif di antara masyarakat, atau dengan kata lain ritual agama yang mereka lakukan merupakan sebuah upaya re-charge bagi manusia untuk mendekatkan diri kembali kepada Tuhannya.

Dirk menyebutkan bahwa di dalam ritual, dia lebih menekankan pada bentuk ritual sebagai penguatan ikatan tradisi sosial dan individu dengan struktur sosial dari kelompok. Integrasi ini dikuatkan dan diabadikan melalui simbolisasi ritual atau mistik. Jadi ritual dilihat sebagai perwujudan esensial dari kebudayaan. Lebih lanjut dinyatakan bahwa ritual adalah as dramatizing the basic myths and vision of reality, the basic values and moral truths, upon which...(T)he world rest. ${ }^{21}$

Sebagaimana yang diungkapkan oleh Ali Handoyo (71 tahun) bahwa etnis Tionghoa yang lahir dan hidup di Jawa merasakan betul bahwa tradisi, budaya dan ritual Jawa sarat dengan kebijaksanaan hidup dan itu saling mengisi dengan sikap atas keyakinan agama yang mereka miliki yang bersinergi menjadi suatu kekuatan kebaikan dalam menjalin hubungan yang harmonis antar sesama walau berbeda keyakinan agama dan suku bangsa. Pada sisi yang lain etnis Tionghoa yang tinggal dan berbaur dengan masyarakat Ketanggi tetap melestarikan tradisi etnis Tionghoa, salah satunya adalah gong zhui; yaitu pertemuan rutin diantara etnis Tionghoa di Kelurahan Ketanggi, acara ini selain temu akrab juga biasanya membahas isu-isu dan topik bisnis dan pada sesi akhir acara mereka mengumpulkan sumbangan yang nantinya digunakan untuk membantu warga disekitar mereka tinggal ataupun sebagai donasi bagi kepentingan amal lainnya (wawancara dengan Ali Handoyo (71 tahun), tanggal tanggal 28 November 2011)

Berdasar uraian diatas peneliti menyimpulkan bahwa kondisi pemahaman dan praktek keagamaan pada masyarakat Ketanggi memiliki kesamaan dengan konsep yang ditawarkan Robert C. Monk. Beliau menyatakan bahwa dalam tradisi keagamaan memiliki dua fungsi utama yang mempunyai peran ganda; yang pertama, tradisi keagamaan sebagai kekuatan yang mampu membuat kestabilan, keterpaduan dan harmonisasi bagi individu dan masyarakat. Yang kedua, tradisi keagamaan berfungsi sebagai agen perubahan dalam masyarakat maupun individu, bahkan dalam situasi konflik sekalipun. ${ }^{22}$ Pemahaman dan praktek keagamaan yang terjadi pada masyarakat Ketanggi memiliki fungsi ganda, pada satu sisi merupakan perakat kestabilan sosial pada sisi yang lain merupakan gerakan perubahan progresif untuk perbaikan kehidupan sosial.

Proses dialektika antara agama dengan budaya lokal Jawa yang terjadi pada masyarakat Ketanggi setidaknya menghasilkan produk budaya sintetis yang merupakan keniscayaan sejarah sebagai hasil dialog antara agama dengan nilai tradisi budaya lokal Jawa. Lahirnya ekspresi-ekspresi ritual yang nilai instrumennya merupakan produk lokal, sedangkan muatan materinya bernuansa religius keagamaan. Keterkaitan antara agama dan budaya pada masyarakat Ketanggi tidak serta merta menghilangkan nilai- nilai fundamental dari ajaran agama yang mereka yakini. Begitu juga halnya dengan tradisi dan budaya etnis Tionghoa, masyarakat etnis Tionghoa yang tinggal di 
Ketanggi walaupun telah memeluk agama yang menjadi pilihan hidup mereka tetap menjaga dan memelihara tradisi dan budaya para leluhur mereka.

\section{ANALISA KOMITMEN KEAGAMAAN MASYARAKAT KETANGGI TERHADAP PLURALITAS AGAMA}

Perbedaan ciptaan Tuhan di tengah alam semesta adalah suatu keniscayaan yang patut diterima sebagai anugerah yang harus disyukuri. Hal demikian harus menjadi lebih nyata pada hidup beragama di tengah keberagaman agama sebagai keniscayaan yang diterima dan disyukuri sebagai anugerah Allah.

Sebagaimana pendapat Ir. Henry Suwarto (53 tahun), beliau mengatakan bahwa dalam ajaran agama Kristen (Katolik) juga senada dengan agama-agama yang lain. Pemuka atau tokoh agama menghimbau para jemaat agar dapat hidup berdampingan dengan umat agama yang lain, supaya terjadi kerukunan umat beragama dan lingkungan yang kondusif tanpa ada masalah antara warga yang satu dengan warga yang lainnya. Karena ajaran Kristen yang diajarkan oleh Yesus Kristus Atau Isa adalah ajaran kasih. Jadi individu yang percaya pada Yesus hidupnya harus penuh kasih untuk menunjukan bahwa di dalam orang Kristen ada kasih salah satu caranya adalah dengan hidup berdampingan dan tanpa pertikaian dengan umat beragama yang lain (hasil wawancara dengan pendeta Ir. Henry Suwarto, pimpinan jemaat Gereja Utusan Pantekosta di Indonesia Ngawi pada tanggal 10 Desember 2011).

Secara hakiki, manusia adalah manusia ciptaan Allah sehingga saling berbeda tidak mengharuskan seorang untuk berlaku tak adil dengan membeda-bedakan seorang dengan dirinya sendiri atau dengan orang lain atau dengan memperlakukan sesama secara diskriminasi karena berbeda agama, etnis, atau status dan lain sebagainya. Keinginan untuk hidup damai, rukun berdampingan antar umat beragama merupakan representasi keinginan untuk hidup bermakna bagi diri, keluarga dan lingkungan masyarakat. Sebagai motivasi utama hasrat ini mendambakan diri agar menjadi seseorang yang bermartabat, terhormat dan berharga (being somebody) dengan kegiatan-kegiatan yang terarah pada tujuan hidup yang dan bermakna.

Hanna Djumhana Bastaman menjelaskan setidaknya ada tiga nilai yang merupakan sumber makna hidup, yaitu: ${ }^{23}$

a. Creative values (nilai- nilai kreatif), bekerja dan berkarya serta melaksanakan tugas dengan keterlibatan dan tanggungjawab penuh pada pekerjaan yang merupakan sarana untuk menemukan dan mengembangkan makna hidup. Makna hidup bukan terletak pada pekerjaan melainkan pada sikap dan cara kerja yang mencerminkan keterlibatan pribadi. Berbuat kebajikan dan melakukan hal-hal yang bermanfaat bagi lingkungan termasuk usaha untuk merealisasikan nilai-nilai kreatif,

b. Experiental values (nilai-nilai penghayatan), menyakini dan menghayati kebenaran, kebajikan, keindahan, keadilan, keimanan dan nilai-nilai berharga lainnya. Cinta kasih merupakan nilai yang sangat penting dalam mengembangkan hidup bermakna. Mencintai seseorang berarti menerima sepenuhnya keadaan orang yang dicintai apa adanya,

c. Attitudinal values (nilai-nilai bersikap), menerima dengan tabah dan mengambil sikap yang tepat dalam pelbagai persoalan hidup dengan terus mengupayakan secara 
optimal cara mengatasinya. Persoalan yang datang dalam bentuk musibah dapat memberikan makna hidup jika mampu mengatasinya dengan baik, tentunya setelah diupayakan usaha- usaha untuk mengatasinya. Optimisme dalam menghadapi musibah, persoalan hidup tersirat dalam ungkapan seperti; makna dalam derita (meaning in suffering) dan hikmah dalam musibah (blessing in disguise).

Bapak Rohmat (60 tahun), Tokoh Agama Ketanggi menyebutkan bahwa proses pembumian nilai-nilai ajaran Islam dan proses dialog antar agama yang kondusif di wilayah Ketanggi melalui proses perjalanan panjang dan dialog yang intens. Beliau mengungkapkan bahwa daerah sekitar Jalan Dr. Sutomo Ketanggi dahulunya, pada era tahun 1980an merupakan surga bagi penggemar minuman keras. Dengan intensitas kegiatan dakwah dan ditunjang komitmen para pemuka agama Islam yang menginginkan perubahan dan adanya tempat ibadah bagi umat Islam maka atas swadaya masyarakat muslim pada waktu itu dibantu dukungan moril dan materiil dari perangkat kelurahan Ketanggi maka didirikanlah masjid Darul Jannah yang letaknya bersebelahan dengan Gereja Utusan Pantekosta di Indonesia.

Dengan adanya masjid, suasana keagamaan mulai menggeliat dan kegiatan mabuk-mabukan perlahan-lahan mulai hilang. Suasana religius mulai nampak seiring dengan berdirinya masjid Darul Jannah yang bersebelahan dengan gereja Utusan Pantekosta di Indonesia Ngawi yang lebih dulu berdiri pada tahun 1986. Proses pembangunan masjid Darul Jannah sendiri berjalan lancar melalui dialog yang intens diantara pemuka agama dalam memahami arti perbedaan agama diantara mereka dalam menciptakan kehidupan bermasyarakat yang harmonis (wawancara dengan Rahmat (60 tahun) pada tanggal 20 November 2011).

Keragaman agama sebagaimana keragaman etnis, suku dan bangsa, juga dipahami dalam satu perspektif kemanusiaan yang hidup berdampingan pada masyarakat Ketanggi dengan kekhasannya membangun kehidupan bersama, keunikan-unikan ini bukanlah ancaman terhadap pemeluk agama yang satu terhadap eksistensi agama yang lainnya, tetapi akan lebih memperjelas keunikan sendiri. Sebagaimana yang dikemukakan oleh Damami bahwa masyarakat Jawa terdapat pemahaman dan pemaknaan sendiri terhadap agama. "agama ageming aji" dari ungkapan ini muncul pemaknaan-pemaknaan. ${ }^{24}$ Pemaknaan pertama yaitu, bahwa agama merupakan pedoman hidup yang pokok, artinya bahwa agama apa saja mengajarkan atau mengandung ajaran yang serba baik untuk keselamatan dan kesejahteraan hidup masyarakat di dunia ini apa pun agama yang dipeluk sama saja karena semua agama mengajarkan keselamatan.

Persepsi tentang Tuhan pada masyarakat Jawa tergambar dalam ungkapan tan kena kinayangapa; yang mengandung pengakuan bahwa setiap kali orang mencoba melukiskan atau menjelaskan tentang hakekat Tuhan pastilah tidak menggambarkan hakekat Tuhan yang sebenarnya dan seutuhnya. Dalam pemahaman masyarakat Jawa upaya untuk menggapai Tuhan tak lebih dari ibarat, perumpamaan orang-orang buta yang meraba gajah. Ada yang memegang gading, ada yang memegang perut, ada yang memegang ekor, ada yang memegang kaki. Masing-masing mempunyai penghayatan berbeda tentang 
makhluk yang bernama gajah itu. Menyadari kenyataan tersebut masyarakat Ketanggi tidak suka memperdebatkan pendirian atau keyakinan tentang Tuhan dan agamanya. Mereka tidak pernah menganggap bahwa kepercayaan atau keyakinannya adalah yang paling benar dan yang lain salah. Sikap inilah yang merupakan kekuatan masyarakat Jawa dalam membangun kerukunan, toleransi baik di bidang kehidupan beragama maupun di bidang-bidang yang lain.

Kerukunan umat beragama juga terlihat pada keharmonisan hubungan antar pemeluk agama. Salah satunya membantu pembangunan tempat ibadah bagi agama lain, kegiatan tertentu, peringatan hari-hari besar keagamaan dan kegiatan lainnya tentunta dengan syarat adanya persetujuan dari dua belah pihak. Partisipasi dan keikutsertaan ini bisa berwujud sumbangan dana maupun material pada acara-acara sosial dan agama yang dilakukan dengan sukarela tanpa paksaan (Hasil wawancara dengan Didik, Kasi Kesra Kelurahan Ketanggi, pada tanggal 25 Oktober 2011).

Kerukunan umat beragama masyarakat Ketanggi terjalin dengan harmonis merupakan kerja keras para pemuka agama masing-masing yang disosialisasikan kepada para jemaatnya. Pemerintahan Kabupaten dalam hal aparat Kelurahan Ketanggi bekerja sama dengan pemuka agama menciptakan kerukunan umat beragama dengan pemikiran pemikiran atau pemahaman masyarakat Ketanggi bahwa agama atau kepercayaan itu hanyalah salah satu alat bagaimana individu atau masyarakat dapat mencapai tujuan hidup yaitu menuju alam suci atau surga. Jadi dengan kata lain semua agama itu baik, semua agama mengajarkan kebaikan.
Pemikiran atau pemahaman ini yang digunakan aparat Kelurahan Ketanggi untuk menjaga kerukunan umat beragama. Oleh para pemuka atau tokoh agama yaitu Islam, Kristen, Hindu dan Buddha pemahaman ini dibawa atau disosialisasikan kepada para jemaat atau pengikutnya. Sosialisasi ini dilakukan setiap ada kegiatan agama. Misal untuk agama Islam dilakukan saat pengajian, yasinan, tahlilan di setiap masjid dan musholla. Untuk agama Kristen disampaikan saat kebaktian minggu atau hari-hari lain di gereja. Untuk agama Budha dilakukan saat ada ritual Sembahyang di Klenteng dan pada saat hari-hari besar agama Buddha, yang mengajarkan tentang arti penting dalam membangun harmoni, menciptakan kerukunan antar umat beragama yang disampaikan pada pada saat upacara ritualnya.

Komitmen keagamaan pada masyarakat Ketanggi dalam keragaman agama terepresentasi secara unik pada tokoh-tokoh agamanya. Hal ini dapat dilihat dari komitmen keagamaan para tokoh agamanya untuk membangun suasana kehidupan keberagaman agama yang harmonis di Kelurahan Ketanggi. Sebagaimana teori yang digagas Durkheim bahwa "religion as a societal glue", agama walau pada satu sisi bersifat destruktif akan tetapi pada sisi yang lain merupakan wahana konstruktif bagi adanya interaksi dan dialog antar umat beragama.Tri Dayakisni dan Hudaniah (2009: 160), mengatakan bahwa komitmen adalah suatu perasaan kelekatan dan niat untuk memelihara hubungan. Duffy dan Rusbult (1986) menyatakan bahwa orang akan lebih komitmen pada suatu hubungan ketika: (1) mereka puas dengan hasil yang mereka peroleh; (2) tidak adanya alternatif hubungan 
lain yang dapat dimasukinya; dan (3) mereka telah menginvestasikan beberapa sumber yang cukup besar dalam hubungan seperti itu (seperti waktu, usaha, pengungkapan diri, persahabatan timbal-balik dan berbagi milik).

Berbicara komitmen, masyarakat Ketanggi tidak bisa dilepaskan dari adanya interaksi sosial diantara mereka, dimana proses tersebut terdapat hubungan timbal-balik, saling mempengaruhi dan pada satu sisi saling menguatkan identitas mereka sebagai masyarakat Jawa yang memiliki kewajiban menjaga harmoni diantara mereka. Soekanto mendefinisikan interaksi sosial sebagai hubungan antar orang- perorang atau dengan kelompok manusia. Interaksi sosial tak akan mungkin terjadi apabila tidak memenuhi dua syarat: (1) adanya kontak sosial, dan (2) adanya komunikasi. ${ }^{25}$

Menurut Glock \& Stark ada lima macam dimensi keberagaman, yaitu dimensi keyakinan (ideologis), dimensi peribadatan atau praktek agama (ritualistik), dimensi penghayatan (eksperiensial), dimensi pengamalan (konsekuensial), dimensi pengetahuan agama (intelektual).

Keberagamaan atau aktifitas beragama bukan hanya terjadi ketika seseorang melakukan perilaku ritual (beribadah), tetapi juga ketika melakukan aktifitas lain yang didorong oleh kekuatan supranatural. Bukan hanya yang berkaitan dengan aktifitas yang tampak dan dapat dilihat mata, juga aktifitas yang tak tampak dan terjadi dalam hati seseorang. ${ }^{26}$

Pengurus Klenteng Sien Hien Kyong, Ngawi Ali Handoyo (71 tahun) mengatakan bahwa komitmen untuk selalu menjaga kerukunan umat beragama dengan cara menghimbau kepada anggota jemaatnya untuk tidak fanatik, sebab rasa fanatik akan menimbulkan perasaan-perasaan atau tindakan yang tidak baik. Pemahaman ini didasarkan pada kenyataan mayoritas pemeluk agama Kristen dan Kong Hucu merupakan etnik Tionghoa, yang secara historis merupakan warga pendatang bukan penduduk asli Ketanggi.

Mengenai karakteristik masyarakat Ketanggi sebagaimana disampaikan oleh Purwoko (47 tahun), Ketua Takmir Masjid Darul Jannah Ketanggi, beliau mengatakan memang ada keunikan terutama pada aspek keberagaman masyarakat di Ketanggi. Beliau menunjukkan adanya keberadaan masjid dan gereja yang bisa berdiri saling berdekatan, bagaimana komunitas muslim mampu berdampingan, hidup bersama dengan komunitas pemeluk agama Kristen dengan harmonis.

Beliau selanjutnya menerangkan bahwa secara historis gereja Utusan Pantekosta di Indonesia yang terlebih dahulu berdiri pada tahun 1986, setelah itu pada tahun 1998 baru di bangun masjid Darul Jannah. Inisiatif untuk membangun masjid Darul Jannah Ketanggi bersebelahan dengan Gereja Pantekosta Utusan Dunia bukanlah bertujuan untuk membatasi gerak para jemaat gereja dalam beribadah akan tetapi pembangunan masjid Darul Jannah sematamata menjawab kebutuhan umat muslim di Ketanggi berkenaan dengan tempat ibadah bagi mereka.

Hubungan antar umat beragama yang terjadi antara umat Muslim dengan para pengurus dan jemaat Gereja berjalan secara wajar, dan selama perjalanan pelaksanaan ibadah tidak pernah terjadi masalah, apalagi sampai bentrok fisik. Hal itu bisa terjadi karena memang diantara tokoh agama dan pemeluk agama di wilayah Ketanggi berupaya melakukan dialog dalam menyelesaikan 
permasalahan diantara mereka, terutama untuk menghindari hal-hal yang tidak diinginkan, yaitu kerusuhan atas nama agama di wilayah Ketanggi.

Pada masa awal berdirinya masjid Darul Jannah sempat terjadi kesalahpahaman, kurangnya komunikasi pada saat pelaksanaan ibadah kami umat muslim dengan pelaksanaan ibadah jemaat gereja, akan tetapi setelah dilakukan upaya dialog antara pengurus masjid dengan pengurus Gereja Baptis Ngawi dapat dicapai kesepakatan untuk bisa saling memahami dan menghargai terutama pada waktu-waktu pelaksanaan ibadah yang dilakukan diantara mereka (Hasil wawancara dengan Purwoko pada tanggal 25 November 2011). Dari apa yang disampaikan beberapa tokoh agama dan aparat kelurahan di atas, tercermin bahwa upaya untuk menjaga stabilitas dan harmonisasi keberagaman agama dilakukan secara kontinyu dan berkesinambungan dalam bentuk komitmen dan toleransi yang dibangun diantara pemuka agama, aparat dan masyarakat Ketanggi. Kultur budaya dan tradisi masyarakat Jawa yang mengedepankan harmoni memberikan pengaruh yang kuat pada masyarakat Ketanggi.

Komitmen masyarakat Ketanggi dalam bentuk apresiasi terhadap pluralitas mampu mencegah terjadinya konflik agama dan terbukti mampu menciptakan iklim yang harmoni dan kondusif bagi pluralitas kehidupan beragama di masyarakat Ketanggi. Inilah yang digambarkan oleh Durkheim bahwa agama dalam bentuk pemahaman pemeluknya memiliki fungsi sebagai perekat sosial. Masyarakat Ketanggi menyakini bahwa ajaran agama mengharuskan pemeluknya untuk senantiasa hidup rukun dan harmonis, itulah yang menjadi kekuatan Ketanggi sebagai model percontohan bagaimana komitmen keagamaan mendasari setiap aktifitas gerak dan laku para pemeluk agama untuk bisa menghadirkan suasana yang damai, aman dan tentram.

Budaya masyarakat Ketanggi merupakan perwujudan budaya masyarakat Jawa mendukung turut andil bagi terwujudnya situasi yang kondusif bagi kehidupan keagamaan. Komitmen keagamaan yang dibangun masyarakat Ketanggi dalam pluralitas agama tidak bisa dilepaskan begitu saja dari adanya pengaruh budaya masyarakat Jawa. Bagi masyarakat Jawa, khususnya pada masyarakat Ketanggi beranggapan bahwa agama hanyalah sebagai "kawan seiring nilai leluhur" sebagaimana yang diungkapkan oleh Muhamad Damami. Beliau menjelaskan bahwa nilai-nilai leluhur yang berjalan seiring dengan ajaran agama. Dengan kata lain nilainilai leluhur yang terbungkus dalam tradisi dan filosofi hidup melengkapi nilai-nilai ajaran agama.

\section{KESIMPULAN}

Kajian dialektika agama dan budaya pada masyarakat Jawa dalam analisa Nico Syukur Dister disebutkan bahwa interaksi budaya dan agama pada sisi lain berpotensi mereduksi nilai-nilai sakral ajaran agama itu sendiri. ${ }^{27}$ Ia menjelaskan bahwa ada bahaya yang mengancam ketika agama dan etika digabungkan sedemikian erat; yang pertama, agama dan etika menjadi kehilangan intensi dan kekhasan sendiri. Intensi agama adalah bergaul dengan Tuhan, pergaulan dengan Tuhan tidaklah sama dengan hidup berperikemanusiaan. Nilai-nilai moral bersifat otonom. Kedua, adalah ancaman apabila orang memakai agama sebagai sarana untuk menjamin lancarnya kehidupan sosio- 
moral ialah disalahgunakannya agama oleh para penguasa masyarakat untuk mempertahankan status quo yang menguntungkan kedudukan penguasa yang bersangkutan.

Melihat argumentasi yang dikemukakan oleh Nico Syukur Dister di atas dalam menganalisa apa yang terjadi pada proses dialog antara agama dan etika (tradisi budaya) di masyarakat Ketanggi pada satu sisi memang benar adanya. Sakralitas nilai ajaran agama pada masyarakat Ketanggi boleh dikatakan menjadi bias, tereduksi oleh nilainilai ritualistik budaya masyarakat Jawa. Proses tarik ulur yang terjadi antara ritual agama dan ritual budaya pada masyarakat Ketanggi sedemikian khas sebagaimana masyarakat Jawa pada umumnya dengan kentalnya nuansa budaya dan tradisi dalam upacara-upacara ritual keagamaan.

Diperlukan kajian yang mendalam dan fokus pada interaksi budaya dan agama pada upacara keagamaan pada masyarakat Jawa. Hal ini dikarenakan komitmen keagamaan pada masyarakat Ketanggi pada satu sisi hadir dari pengaruh yang timbul dari pemahaman berdasar ajaran-ajaran agama dan pada sisi yang lain, komitmen keagamaan yang dibangun masyarakat Ketanggi memiliki nuansa budaya Jawa yang sangat kental.

Ada kekhawatiran ketika agama dan budaya digabungkan sedemikian rupa, sebagaimana kekhawatiran yang disampaikan Nico Syukur, proses tersebut menghilangkan intensi, kekhasan agama sebagai sesuatu yang "taken for granted" Ilahiyah dengan etika yang bertumpu pada budaya manusia. Bahkan pada sisi yang lain pemaksaan atas nama agama dalam menjaga stabilitas sosial dan untuk mempertahankan status quo bagi para penguasa.
Berdasar analisa diatas maka dapat peneliti simpulkan bahwa proses dialog intens antara agama dan budaya pada masyarakat Ketanggi dan masyarakat Jawa -pada umumnya- menjadikan keadaan dimana agama pada suatu saat berfungsi sebagai landasan legal formal atas tradisi-tradisi budaya di masyarakat. Keadaan seperti ini bisa menimbulkan bias dan reduksi ajaran agama oleh selubung perilaku ritual-budaya masyarakat Ketanggi sebagai representasi masyarakat Jawa itu sendiri. Dialektika agama dan budaya pada masyarakat Ketanggi lebih condong pada penguatan legalitas budaya sebagai penggerak kesadaran kolektif bila dibandingkan dengan kekuatan moralitas sosial agama.

\section{CATATAN AKHIR}

1 Komarudin Hidayat, "Ilmu Perbandingan Agama: Ketegangan antara Dialog dan Dakwah", Ulumul Qur'an, Jurnal Ilmu dan Kebudayaan, No. I, Vol. IV. h. 11.

2 Paul Stange,. Politik Perhatian: Rasa dalam Kebudayaan Jawa (terj.) (Yogyakarta: LKIS, 1998).

3 Muhamad Damami, Makna Agama dalam Masyarakat Jawa (Yogyakarta: LESFI, 2002)

4 Sujamto, Re-Oreintasi dan Revitalisasi: Pandangan Hidup Masyarakat Jawa (Semarang: Dahara Prize, 1992).

5 Muhaimin A.G., Islam dalam Bingkai Budaya Lokal Potret di Cirebon (Jakarta: PT. Logos Wacana Ilmu, 2001).

6 Denys Lombard, Nusa Jawa, Silang Budaya (Jakarta: Gramedia Pustaka Utama, 2005), h. 1.

7 Balai Penelitian, Pengembangan dan Statistik Kabupaten Ngawi, Ngawi dalam Angka (Ngawi: CV. Mahardika, 2009).

$8 \quad$ Yoseph Yapi Taum, "Wawasan Kebangsaan dari Perspektif Budaya Flores." Makalah Dialog Budaya Daerah "Merumuskan Kembali Wawasan Kebangsaan Melalui Perspektif Budaya Lokal" yang diselenggarakan Balai Kajian Sejarah dan Nilai Tradisional Yogyakarta, 18 - 19 April di Wisma Kinasih Kaliurang, 2006, h. 32.

$9 \quad$ JS. Furnivall, Netherlands India: A Study of Plural Economy (Cambridge: Cambridge University Press, 1967), p. 446.

10 Hendar Riyadi, Melampaui Pluralisme: Etika Al-Qur'an tentang Keragaman Agama (Jakarta: RMBOOKS \& PSAP, 2006), h. 59-60.

11 Sunardi, "Dialog: Cara Baru Beragama, Sumbangan Hans Kung bagi Dialog antar-Agama," dalam Seri DIAN 
I/Tahun I: Dialog Kritik dan Identitas Agama (Yogyakarta: Dian Interfidei, 1994), h. 69.

12 Quraish Shihab, Tafsir Al-Mishbah, Volume 2 (Jakarta: Lentera Hati, 2000), h. 38-39.

13 Sujamto, Re-Oreintasi dan Revitalisasi: Pandangan Hidup Masyarakat Jawa (Semarang: Dahara Prize, 1992), h. 15.

14 Niels Mulder, Kepribadian Jawa dan Pembangunan Nasional (Yogyakarta: Gadjah Mada University Press, 1986), h. 37.

15 http://pujanggagagal.blogspot.com/2011/03/ makalah-budaya-dan kepercayaan html, diakses pada hari Senin tanggal 31 Oktober 2011

16 Koentjaraningrat dan Donald K. Emmerson (eds), Aspek Manusia dalam Penelitian Masyarakat (Jakarta:

Gramedia, 1985), h. 144

17 Djam'annuri, Ekspresi Keagamaan (Yogyakarta: Fakultas Ushuluddin IAIN Sunan Kalijaga), h. 34.

18 Djam'annuri. Ekspresi Keagamaan, h. 34.

19 (http://siji.phpnet.us/index.php/Islam-Budaya-Jawa/ interelasi-nilai-jawa-dan-islam-dalam-bidangkepercayaan-dan-ritual.html, diakses pada hari Senin, tanggal 31 Oktober 2011).

20 Djam'annuri. Ekspresi Keagamaan, 35.

21 Nur Syam, Islam Pesisir (Yogyakarta: Penerbit LKIS, 2005), h. 19.

22 Jalaluddin Rakhmat, Psikologi Agama Sebuah Pengantar (Jakarta: Penerbit Mizan, 2004), h. 227.

23 Hanna Djumhana Bastaman, Integrasi Psikologi dengan Islam; Menuju Psikologi Islami (Jakarta: Pustaka Pelajar, 2005), cet. IV. h. 195.

24 Muhamad Damami, Makna Agama dalam Masyarakat Jawa (Yogyakarta: LESFI 2002)

25 Tri Dayakisni dan Hudaniah, Psikologi Sosial (Malang: UMM Press, 2009), h. 160.

26 Djamaludin Ancok dan Fuat Nashori Suroso. Psikologi Islami; Solusi Islam atas Problem-problem Psikologi (Yogyakarta: Penerbit Pustaka Pelajar, 2008), h. 76-77

27 Nico Syukur Dister, Pengalaman dan Motivasi Beragama, h. 102.

\section{DAFTAR PUSTAKA}

Ancok, Djamaludin dan Fuat Nashori Suroso. 2008 Psikologi Islami; Solusi Islam atas Problem-problem Psikologi, Yogyakarta: Penerbit Pustaka Pelajar. cet. VII

Balai Penelitian Pengembangan dan Statistik Kabupaten Ngawi. 2009. Ngawi dalam Angka, Ngawi: CV. Mahardika.

Bastaman, Hanna Djumhana. 2005. Integrasi Psikologi dengan Islam; Menuju Psikologi Islami, Jakarta: Pustaka Pelajar, cet. IV.

Damami, Muhamad. 2002. Makna Agama dalam Masyarakat Jawa, Yogyakarta: LESFI.

Dayakisni, Tri dan Hudaniah. 2009. Psikologi Sosial, UMM Press, Malang.

Dister, Nico Syukur. 1994. Pengalaman dan Motivasi
Beragama, Yogyakarta: Penerbit Kanisius.

Djam'amnnuri. 1997. Ekspresi Keagamaan, Yogyakarta: Fakultas Ushuluddin IAIN Sunan Kalijaga.

Furnivall, JS. 1967. Netherlands India: A Study of Plural Economy, Cambridge at The University Press.

Hidayat, Komarudin. 1993. Ilmu Perbandingan Agama: Ketegangan antara Dialog dan Dakwah, Ulumul Qur'an, Jurnal IImu dan Kebudayaan, No. I, Vol. IV.

Koentjaraningrat dan Donald K. Emmerson (eds.). 1985. Aspek Manusia dalam Penelitian Masyarakat, Jakarta: Penerbit PT Gramedia.

Lombard, Denys. 2005. Nusa Jawa, Silang Budaya (terj.). Jakarta: Gramedia Pustaka Utama.

Muhaimin, A.G. 2001. Islam dalam Bingkai Budaya Lokal Potret di Cirebon. Jakarta: PT. Logos Wacana IImu.

Mulder, Niels. 1986. Kepribadian Jawa dan Pembangunan Nasional. Yogyakarta: Gadjah Mada University Press.

Najati, Utsman. 1985 Al- Qur'an dan Ilmu Jiwa Agama. Bandung: Pustaka.

Rakhmat, Jalaluddin. 2004. Psikologi Agama Sebuah Pengantar. Jakarta: Penerbit Mizan.

Riyadi, Hendar. 2006. Melampaui Pluralisme: Etika Al-Qur'an tentang Keragaman Agama, Jakarta: RMBOOKS \& PSAP.

Shihab, Quraish. 2000. Tafsir Al-Mishbah, Volume 2, Jakarta: Lentera Hati.

Stange, Paul. 1998. Politik Perhatian: Rasa dalam Kebudayaan Jawa (terj.) Yogyakarta: LKIS.

Sujamto. 1992. Re-Oreintasi dan Revitalisasi: Pandangan Hidup Masyarakat Jawa Semarang: Dahara Prize.

Suseno, Franz Magniz. 2003. Etika Jawa; Sebuah Analisa tentang Kebijaksanaan Hidup Jawa. Jakarta: PT. Gramedia Pustaka Umum

Sunardi, ST. 1994 "Dialog: Cara Baru Beragama, Sumbangan Hans Kung bagi Dialog antar-Agama," dalam Seri DIAN I/Tahun I: Dialog Kritik dan Identitas Agama, Yogyakarta: Dian

Syam, Nur. 2005. Islam Pesisir, Yogyakarta: Penerbit LKIS.

Taum, Yoseph Yapi. 2006. "Wawasan Kebangsaan dari Perspektif Budaya Flores." Makalah Dialog Budaya Daerah "Merumuskan Kembali Wawasan Kebangsaan Melalui Perspektif Budaya Lokal" yang diselenggarakan Balai Kajian Sejarah dan Nilai Tradisional Yogyakarta, 18 - 19 April 2006 di Wisma Kinasih Kaliurang.

\section{Internet}

http://pujanggagagal.blogspot.com/2011/03/makalahbudaya-dan kepercayaan diakses pada hari Senin tanggal 31 Oktober 2011

http://siji.phpnet.us/index.php/Islam-Budaya-Jawa/ interelasi-nilai-jawa-dan-islam-dalam-bidangkepercayaan-dan-ritual.html 